\title{
Trabalho, práxis social e Educação: notas para uma teoria da atividade educativa
}

\author{
Epitácio Macário*
}

\section{Resumo}

$\mathrm{O}$ artigo discute a natureza e a especificidade da atividade educativa no âmbito da práxis social. Expôe, inicialmente, as categorias "objetivação" e "apropriação" como momentos constitutivos do trabalho e da práxis social. Sobre estes fundamentos, mostra a necessidade, a função social, o sujeito e o objeto da atividade educativa. O texto fundamenta-se no pensamento de Lukács e Leontiev.

Palavras-chave: Educação. Aspectos sociais. Educação para o trabalho.

* Doutor em Educaçáo pela Universidade Federal do Ceará. Professor de Economia Política e Filosofia do Trabalho na Universidade Estadual do Ceará (UECE). 


\section{Situando o problema}

O discurso do senso comum fundamenta-se, regra geral, em concepçóes que foram sedimentadas no fluxo da experiência social, de forma espontânea. Elas resultam de abstraçôes construídas e generalizadas pela prática social, e fundamentam-se na prova empírica, na eficácia da ação, na realização exitosa dos objetivos. Os conceitos e concepçóes assim produzidos apresentam-se como evidentes, pois sua eficácia não depende do questionamento, senão da sua instrumentalização nos atos cotidianos. Por isto, são assimilados e professados irrefletidamente.

A ciência só pode erguer-se sobre a base destas noçôes, conceitos e concepçóes, pois sua necessidade, seu interesse e seu objeto provêm, precisamente, da prática social, do próprio cotidiano. Todavia, o interesse da ciência é descobrir e trazer a lume aquilo que as evidências imediatas não revelam, examinando a matéria em seu pormenor, capturando as relaçóes que se tecem entre os fenômenos e construindo uma concepção mais ampla e totalizadora. Assim, o conhecimento científico pode fecundar o senso comum, tornando-se uma força material.

O presente artigo se fez neste horizonte e tem como objetivo, unicamente, situar o problema da natureza e especificidade da educação no gradiente de atividades que estruturam o ser social. $\mathrm{O}$ artigo tem o interesse de contribuir para a superação das noçôes de educaçáo sedimentadas no senso comum, lançando mão do pensamento de Leontiev e Lukács, dois expoentes do materialismo dialético. Seguem-se, pois, as sendas abertas pelos eminentes professores Dermeval Saviani e Newton Duarte.

Parte-se do fato de que, pelo trabalho e pela práxis social, o homem constrói uma experiência social que é fixada em veículos materiais e se defronta com os indivíduos como realidade objetiva, exterior. A formação do indivíduo se processa na medida mesma em que ele se apropria dos produtos desta experiência, incorporando-os ao seu repertório subjetivo. É este o lócus onde germina e opera a atividade educativa.

\section{Filogênese e ontogênese do homem}

A forma como Leontiev e Lukács apanham a diferença entre ontogênese e filogênese dos animais e dos homens é particularmente instrutiva, para 
efeito da conceituação da educação. Ao tratar do comportamento animal, Leontiev (1978, p. 178) assegura que

[...] o comportamento individual do animal depende de uma dupla experiência: a experiência específica, fixada nos mecanismos do comportamento reflexo incondicional instintivo e a experiência individual, formada ontogeneticamente; a função fundamental que assegura os mecanismos de formação da experiência individual consiste numa adaptação do comportamento específico aos elementos mutáveis do meio exterior.

É decisivo compreender que o comportamento dos animais se forma sobre a base dos recursos genéticos fixados no plano da espécie (filogênese), mas também pela assimilação da experiência individual (ontogênese). Principalmente os animais superiores têm uma estrutura morfológica susceptível de mudanças, às vezes muito profundas, o que os capacita para a incorporação dos desafios postos pelas condiçóes ambientais. Assim, não se pode falar de um comportamento baseado unicamente em códigos genéticos incondicionados, dados de uma vez para sempre. Os animais podem desenvolver, a partir da experiência individual, novas formas de comportamento, o que responde pela capacidade de adaptação às condiçóes mutáveis da natureza circundante. Todavia, e isto é central, na sequencia da citação lê-se que "[...] a função fundamental que assegura os mecanismos de formação da experiência individual consiste numa adaptação do comportamento específico aos elementos mutáveis do meio exterior." (LEONTIEV, 1978, p. 178) Em outras palavras, a formação de novos comportamentos está na razão direta da capacidade de fixação no plano morfológico, portanto na filogenia, das mudanças requeridas pelo meio. Esta adaptação não ultrapassa, pois, o determinismo biológico; ao contrário, ela tem nas premissas genéticas da espécie não apenas sua possibilidade, mas seu limite superior. Um novo comportamento (ontogênese) se engendra e se mantém somente se é abrigado na morfologia animal, se é incorporado no patrimônio genético da espécie.

Na mesma linha, Lukács argumenta que a capacidade de adaptação dos seres vivos não deve ser menosprezada. Com efeito, cada exemplar de uma espécie viva se defronta com um ambiente concreto, “[...] cuja constância 
ou mudança incide a fundo sobre o processo da reprodução biológica em sentido tanto ontogenético quanto filogenético" (LUKÁCS, 1981b, p. 177). $\mathrm{O}$ animal trava um conjunto de açóes recíprocas com o meio de modo tal que termina incorporando mudanças morfológicas muito significativas. Entretanto, não se pode esquecer que "[...] o momento predominante [destas açóes recíprocas] é constituído pelo modo como o ambiente age sobre os seres vivos, estimula, permite ou impede a reprodução; é isto que determina, em definitivo, a conservação ou extinçẫo das espécies, dos gêneros etc.” (LUKÁCS, 1981b, p. 177). Quando as circunstâncias do meio ultrapassam a capacidade de mudanças no aparato biológico, as espécies entram em extinção.

Neste particular, o filósofo húngaro Lukács está lidando com as mesmas categorias do psicólogo russo Leontiev, ao tratar da evoluçáo biológica. Ambos consideram que o comportamento dos seres vivos se forma sobre a base de duas experiências: aquela determinada pela carga genética assimilada no plano da espécie (genótipo) e aquela advinda da competição dos indivíduos com o meio ambiente. Esta segunda experiência só pode se afirmar definitivamente sobre a base de mutaçóes morfofisiológicas dos organismos vivos, razão por que ela tem como limite intransponível as possibilidades de adaptação dadas na constituição biológica de cada ser. Desta forma, ela surge no plano dos indivíduos, mas é incorporada no patrimônio genético porque ela opera por meio de transformaçóes na própria estrutura do organismo vivo. Ademais, as transformaçôes sofridas no organismo em função das interaçóes deste com o meio têm como momento predominante precisamente os imperativos externos, postos pelo ambiente. O homem, como ser vivo, está sujeito a estas mesmas leis evolutivas. Entretanto, ele póe em ser um terceiro tipo de experiência que já não é determinado pela sua estrutura biológica.

O indivíduo humano, diz o psicólogo russo, como ente pertencente a uma espécie viva, também incorpora estas dimensóes: é dotado de propriedades biológicas que definem sua espécie e incorpora mutações nesta estrutura genética a partir da experiência de vida dos indivíduos singulares. Nas suas palavras: "O homem não está evidentemente subtraído ao campo de ação das leis biológicas”. Não obstante, “[...] as modificações biológicas hereditárias não determinam o desenvolvimento sócio-histórico do homem e da humanidade; este é doravante movido por outras forças 
que não as leis da variação e da hereditariedade biológicas" (LEONTIEV, 1978, p. 264). Existe um abismo que separa a ontogênese no animal e na espécie humana, porque, nesta última, comparece "[...] um terceiro tipo de experiência, a experiência sócio-histórica de que o homem se apropria no decurso do seu desenvolvimento ontogenético" (LEONTIEV, 1978, p. 178). Esta experiência não é idêntica à experiência individual, tampouco é determinada por algum mecanismo genético. Ela é em tudo diferente daquela dos animais precisamente porque se trata de algo construído no curso da atividade social dos homens. Ela é fruto de um processo em que as atividades singulares dos indivíduos se interpenetram ou se sintetizam por meio de relaçóes sociais, objetivando e exteriorizando um conjunto de objetos e forças sociais que são transmitidos de geração a geração. $\mathrm{O}$ autor caracteriza esta experiência da seguinte forma:

Esta experiência é específica no sentido em que não se forma na vida dos diferentes indivíduos, mas é produto do desenvolvimento de numerosas geraçóes e transmite-se de uma geração a outra. Todavia não é fixada pela hereditariedade e é nisso que reside a sua diferença radical com a experiência específica dos animais. Se bem que ela se adquira no decurso do desenvolvimento ontogênico do homem, não podemos identificá-la com a experiência individual propriamente dita. Ela distingue-se, por um lado, pelo seu conteúdo, o que é evidente, e, por outro, pelo princípio do seu mecanismo de aquisição e de apropriação. (LEONTIEV, 1978, p. 178).

Dois aspectos desta citação merecem ser explorados. O primeiro diz respeito ao fato de que a experiência histórica, aquela que constitui a generalidade do homem, consiste numa objetivação da práxis social dos homens, portanto trata-se de uma realidade fixada exteriormente, e não mais de uma dimensão imediatamente presente nos indivíduos. É precisamente esta experiência objetivada e exteriorizada no curso da atividade humana que constitui o gênero humano. Consequentemente, a dimensão genérica não coincide imediatamente com os indivíduos porque é construída, é posta, é objetivada, é exteriorizada pela atividade humana. O segundo aspecto respeita à forma como esta experiência se realiza no plano subjetivo. Como 
exterioridade posta, ela deve ser apropriada pelos indivíduos como meio de sua inserção no mundo genuinamente humano. $\mathrm{O}$ indivíduo humano traz em si os progressos auferidos no longo processo evolutivo a que está sujeita a espécie homo sapiens. Porém, ainda não é portador da experiência genérica que se formou no curso da história e que se lhe confronta como externalidade. É preciso que o indivíduo desenvolva sobre este patrimônio genérico uma atividade específica por meio da qual a incorpora ao seu repertório subjetivo. O nódulo teórico destas questóes é catalisado nas categorias da objetivação e apropriação, razão por que devemos apresentálas à frente.

\section{Trabalho, objetivação e apropriação}

O trabalho é a atividade por meio da qual o homem se especifica no quadro da natureza precisamente e na medida em que ele proporciona a transformação ativa das condiçóes preexistentes, adequando-as às necessidades humanas. Diferentemente da atividade adaptativa desenvolvida pelos animais, o trabalho atua sobre o meio mudando a forma dos objetos naturais, combinando suas propriedades e inserindo-as em novas conexóes. É assim que se engendram formas de objetividade que, no confronto com a causalidade natural, representam algo ontologicamente novo. Isto é possível, porque o trabalho é uma atividade consciente. Mediado pela consciência, o homem transforma a necessidade e seu objeto em pergunta, isto é, ele toma distância de seu objeto ao antecipar na mente aquilo que pretende realizar. O sujeito póe uma finalidade que, pela sua natureza, se orienta para o futuro - uma ação a realizar, uma transformação que se pretende operar, a construção de um objeto que tenha utilidade em face das necessidades humanas.

O fim posto idealmente (orientado para o futuro) tem de encontrar no próprio objeto, na própria realidade existente, as condiçóes materiais de sua realização, do contrário não resultará em nada efetivo e será suprimido. O sujeito é assim impulsionado a encontrar os meios de efetivação daquele projeto. Impóe-se, por necessidade, que ele reflita as propriedades e forças que podem ser móveis materiais da realização do desígnio posto idealmente e as que se opóem a tal projeto. $\mathrm{O}$ conhecimento da natureza tem, portanto, sua necessidade e seu impulso originário postos pelo trabalho e constitui 
mesmo uma condição de êxito do processo laborativo. Isto não quer dizer que o homem que realiza o trabalho conheça todas as propriedades e forças operantes no objeto, muito menos todas as circunstâncias e conexóes que o circundam. A este respeito, Lukács (1981a, p. 27-28) adverte:

Uma vez que todo objeto natural, todo processo natural tem uma infinidade intensiva de propriedades, de inter-relações com o mundo que o circunda etc., o que dissemos [sobre a necessidade de que o homem se aproprie das leis causais da natureza] só se refere àqueles momentos da infinidade intensiva que têm uma importância positiva ou negativa em face da posição teleológica. Se para trabalhar fosse necessário um conhecimento, mesmo que somente aproximado, desta infinidade intensiva em si, o trabalho jamais poderia ter surgido nas fases iniciais da observação da natureza (quando náo havia um conhecimento no sentido consciente).

Tem-se aqui uma questão que merece ser desdobrada, porquanto parece que incorremos em contradição ao afirmar que o êxito do trabalho depende de que o homem se aproprie das propriedades imanentes dos objetos naturais, ao mesmo tempo em que argumentamos que o conhecimento assim auferido jamais pode exaurir toda a infinidade intensiva de propriedades e relaçóes que constituem o objeto. Defrontamo-nos com uma constatação, fartamente enfatizada pela dialética materialista, de que o real é constituído de uma multiplicidade de relaçôes recíprocas, porquanto ele é muito mais amplo e complexo do que o conhecimento que dele temos. Se levarmos em consideração que a realidade natural, e ainda mais a social, se encontra em constante movimento, a tese da náo-identidade entre a realidade exterior e sua expressão na consciência ganha força decisiva.

Esta tese é amplamente explorada por Lukács na caracterização do reflexo como apropriação espiritual da realidade. $\mathrm{Na}$ análise do reflexo, diz o filósofo, "[...] imediatamente encontramos a precisa separação entre objetos, que existem independentemente do sujeito, e sujeitos, que podem reproduzi-los de modo mais ou menos correto mediante atos de consciência, que podem apropriar-se deles espiritualmente" (LUKÁCS, 1981a, p. 36-37). O reflexo surge como atividade da consciência, como apropriação ativa do 
real operada pela consciência. Por esta razão, sua natureza é ontologicamente diferente da realidade da qual é expressão subjetiva. Nas palavras do autor:

No reflexo da realidade a reprodução se destaca da realidade reproduzida, coagulando-se numa "realidade" própria da consciência. Pusemos entre aspas a palavra realidade porque, na consciência, ela é apenas reproduzida; nasce uma nova forma de objetividade, mas não uma realidade, $\mathrm{e}$ - exatamente em sentido ontológico - não é possível que a reprodução seja da mesma natureza daquilo que ela reproduz e muito menos idêntica a ela. (LUKÁCS, 1981a, p. 38).

Lênin (1979, p. 105) já havia se posicionado na mesma direção ao tratar das possibilidades do conhecimento humano. Para ele, uma teoria do conhecimento fundada na dialética materialista não pode "[...] supor jamais que nosso conhecimento é completo e imutável, senão indagar de que maneira o conhecimento nasce da ignorância, de que maneira o conhecimento incompleto e inexato chega a ser mais completo e mais exato". Diz ainda que a perspectiva instaurada por Marx e Engels "[...] reconhece a relatividade de todos os nossos conhecimentos, não no sentido da negação da verdade objetiva, mas no sentido do condicionamento histórico dos limites de aproximação de nossos conhecimentos à verdade" (LÊNIN, 1979, p. 145, tradução nossa).

O nódulo central da diferença ontológica entre sujeito e objeto, reflexo e objeto exterior, conhecimento e realidade, reside no fato de que a apropriação operada pela consciência é ativa. Com justa razão, podemos dizer que não é a realidade que salta para dentro da consciência com toda sua malha determinativa, mas é a consciência que opera a transformação das leis que regem a realidade em representações e conceitos. Esta questão requer, ainda, uma apresentação, mesmo que breve e pontual, da abordagem do psicólogo russo Alexis Leontiev. Dada sua intenção de descobrir e expor as mediaçóes pelas quais se funda e opera o psiquismo humano, sua contribuição pode nos ajudar a precisar aquilo que nos autores retro citados aparece como leis gerais.

Para o psicólogo russo, o homem se faz homem à medida que se apropria da experiência sócio-histórica acumulada objetivamente. A partir 
da análise do processo formativo de uma criança pequena, Leontiev (1978) assegura que a apropriação se dá primeiramente por intermédio de atividades externas. A criança procede por imitação da conduta do adulto. Com o passar do tempo, a atividade imitativa faz brotar os germes do pensamento lógico e da linguagem. Doravante, aproveitando-se destas aquisiçóes funcionais, tem origem um novo e potente tipo de atividade, que se processa internamente, responsável pela interiorização de conceitos e pela realização de operaçóes lógicas. $\mathrm{O}$ percurso destas transformaçóes de atividades externas em atividades internas é assim sumarizado por Leontiev (1978, p. 188):

A ação interior constitui-se, portanto, primeiro, sob a forma de uma ação exterior desenvolvida. Posteriormente, após uma transformação progressiva - generalização, redução específica dos seus encadeamentos, modificação do nível em que se efetua - ela interioriza-se, isto é, transforma-se em ação interior, desenrolando-se inteiramente no espírito da criança.

E mais adiante conclui:

Assim, a aquisição das ações mentais, que estão na base da apropriação pelo indivíduo da "herança" dos conhecimentos e conceitos elaborados pelo homem, supốe necessariamente que o sujeito passe das açóes realizadas no exterior às açóes situadas no plano verbal, depois a uma interiorização progressiva destas últimas; o resultado é que estas açôes adquirem o caráter de operaçóes intelectuais estreitas, de atos intelectuais.

É desnecessário repisar a tese do caráter ativo da apropriação, a não ser para realçar, com muita justiça, a categoria da interiorização como um processo ativo. Esta forma de abordar o problema tem importância seminal para a reta compreensão dos processos de ensino, pois remete ao fato de que o educando interioriza os ensinamentos, sempre mediado por uma atividade específica. Não há como depositar conteúdos na consciência do educando, tampouco garantir com precisão que tais conteúdos sejam assimilados e objetivados na prática social do educando sempre consoante à finalidade 
que preside o ato educativo. Em todo este processo - de assimilação de conteúdos e incorporação em sua conduta -, o educando reage ativamente. Interessa reforçar, pois, esta linha argumentativa, invocando mais uma vez o pensamento do autor:

Devemos sublinhar que este processo [de apropriação] é sempre ativo do ponto de vista do homem. Para se apropriar dos objetos ou dos fenômenos que são o produto do desenvolvimento histórico, é necessário desenvolver em relaçấo a eles uma atividade que reproduza, pela sua forma, os traços essenciais da atividade encarnada, acumulada no objeto. (LEONTIEV, 1978, p. 268).

Abriu-se um longo parêntese para expor a natureza ativa da apropriação operada pela subjetividade. Agora, é possível sumariar que a posição teleológica se divide em dois momentos: a posição do fim e a busca dos meios. No curso deste segundo momento, o homem direciona-se ao objeto no sentido de apanhar e processar mentalmente suas propriedades e forças imanentes. $\mathrm{O}$ reflexo do objeto é realizado por meio de atividades externas e internas, com o que a representação mental não deixa de apanhar os nexos causais decisivos para a realização da finalidade, embora não possa capturar toda a malha determinativa do real. Estas são condiçóes necessárias à efetivação exitosa da posição teleológica, mas não suficientes. Mesmo que o projeto construído subjetivamente seja perfeito - do ponto de vista do fim posto e do conhecimento mais aproximado dos meios de sua realização -, é necessário ainda que o homem (ou grupo de homens) decida realizá-lo praticamente. Sem esta decisão, que só pode se originar na subjetividade, o projeto elaborado mentalmente pode não se tornar ser, vindo a suprimir-se ou a perdurar no estado de potência. Como assinala o professor Sérgio Lessa, "[...] o elo ontológico que articula o reflexo, que participa de uma prévia ideação, com o produto resultante do processo de trabalho, no contexto da ontologia lukacsiana, é a categoria da alternativa" (LESSA, 2002, p. 104).

A categoria da decisão alternativa é central na ontologia de Lukács, com o que a subjetividade assume seu devido lugar no âmbito da práxis humana e do processo histórico. Já pudemos perceber como, na linha argumentativa de Lukács e Leontiev, a consciência é o diferencial ontológico da atividade humana em confronto com a atividade animal, e que a 
apropriação da objetividade externa por ela é ativa. Agora, a categoria da decisão alternativa, como mediação essencial da práxis humana, póe o caráter ativo da subjetividade um degrau acima, haja vista que o órgão e o lugar onde se processa a decisão é a consciência do homem. A decisão se póe, entretanto, como resposta a uma necessidade posta pela sociedade e assumida como posição teleológica do indivíduo. Ainda mais, qualquer decisão só pode se efetivar sobre a base de possibilidades ou alternativas presentes na própria realidade. Nas palavras de Lukács (1981a, p. 49): "É precisamente o processo social real, do qual emergem tanto as finalidades quanto a busca e a aplicação dos meios, que determina, delimitando-o concretamente, o espaço das perguntas e respostas possíveis, das alternativas que podem ser realmente transformadas em prática”.

A clara delimitação das necessidades, que são o momento ontologicamente primário da tomada de decisão, como algo posto pela dinâmica social; a inequívoca defesa das possibilidades e alternativas de escolha como algo dado pela natureza ou posto pela prática social; estes fatos em nada diminuem a força e o poder da subjetividade. Muito pelo contrário. A tese aqui defendida ganha força perante o idealismo subjetivista na medida em que apanha as mediaçóes materiais que constituem os móveis de efetivação da subjetividade. Sem as condiçóes materiais, como pode a consciência subjetiva tornar-se um poder efetivo na construção da história? E, do outro lado, de onde procedem a necessidade e o estímulo para a postulação de finalidades na consciência, senão do próprio intercâmbio ativo que o homem trava com seu meio natural e social?

As categorias expostas acima constituem as mediações internas da atividade humana que a tornam o veículo das transformaçóes da causalidade. Por meio delas, a finalidade posta idealmente fecunda a ordem causal, combinando suas propriedades, colocando-as em novas conexóes, mudando sua forma. Aquilo que era idealidade se torna algo de material, e o que era materialidade preexistente à ação é posto de outra forma, é transformado. Trata-se, aqui, da categoria da objetivação, que se mostra cristalinamente no processo de trabalho. Nas palavras de Marx (1983, p. 151):

No processo de trabalho a atividade do homem efetua, portanto, mediante o meio de trabalho, uma transformação do objeto de trabalho, pretendida desde o princípio. $O$ processo extingue-se no 
produto. Seu produto é um valor de uso; uma matéria natural adaptada às necessidades humanas mediante transformação da forma. O trabalho se uniu com seu objetivo. O trabalho está objetivado e o objeto trabalhado. O que do lado do trabalhador aparecia na forma de mobilidade aparece agora como propriedade imóvel na forma de ser, do lado do produto. Ele fiou e o produto é um fio.

Sobre a base destes desdobramentos, que tomaram o trabalho como objeto, podemos afirmar que a atividade humana é objetivadora. Todavia, é necessário entender que, em que pese a natureza objetivadora que identifica o trabalho e todas as outras atividades sociais, existem diferenças ontológicas entre uma e outra esfera de atividade. Muito embora o conjunto da práxis social tenha se originado, direta ou indiretamente, da produção material da vida e mantenha uma estrutura interna idêntica à do trabalho, não se pode descuidar de suas diferenças ontológicas. Por isto, urge que se esclareçam estas questóes, mesmo que brevemente.

\section{Práxis social, objetivaçáo e apropriaçáo}

No exercício do trabalho, o homem singular não se encontra em relaçáo direta com a natureza, mas sua atuação se dá mediada pela açáo dos outros homens. O próprio aparecimento do trabalho - como atividade consciente - teve como suporte a existência de uma forma de vida gregária. Como asseverou Marx (1991, p. 66) a

[...] comunidade tribal espontânea ou, se preferirmos dizer, a horda constitui o primeiro passo para a apropriaçáo das condiçóes objetivas de vida, bem como da atividade que a reproduz e lhe dá expressão material, tornando-a objetiva (atividade de pastores, caçadores, agricultores etc.).

O surgimento do trabalho e a divisão que o acompanha, como uma sua dimensão orgânica, impulsionaram as comunidades originárias a patamares de socialidade cada vez mais elevados e complexos, ao mesmo tempo em que a complexificação das relações sociais propulsionava a divisão do trabalho para situações novas e mais extensas. A evolução do 
trabalho, da divisão do trabalho e das relações sociais são forças que se determinam reflexivamente.

A consequência imediata disto é que, ao trabalhar, o homem transforma a natureza e a si mesmo, mas também, e primordialmente, entra em relaçóes ativas com os outros. Ergue-se, desta forma, um coletivo, uma forma específica de cooperação que funciona como mediação do exercício do trabalho. A necessidade é, assim, respondida pela interconexão das operaçóes que se processam no interior da atividade coletiva. Por consequência, é este coletivo que trabalha ou a forma de cooperação específica quem elabora a lei que rege as açóes singulares ou a conduta dos indivíduos no interior da atividade coletiva. A lei é, portanto, processada socialmente e assume perante os indivíduos o caráter de valores que normatizam a prática social de cada um. Da mesma forma que o trabalho objetiva valores de uso (que formam a base material dos valores de troca), a práxis social objetiva os valores que servem de parâmetro e norma da conduta dos indivíduos. Estas objetivaçóes encontram na esfera do hábito, dos costumes, da moral sua forma de existência material, sendo apropriadas pela subjetividade sob a forma de dever-ser (FORTES, 2001). Assim, tanto os valores ditos materiais (engendrados no processo de transformação da natureza) quanto os espirituais (morais, estéticos, éticos) são resultado da atividade humana no trabalho e na práxis social. O conhecimento que brota e opera como um momento do trabalho e da práxis social também tem de se objetivar, pois somente assim garante seu acúmulo e continuidade no fluxo da história.

No curso do trabalho, os homens póem os objetos sob prova prática, fazendo com que as propriedades imanentes destes - até mesmo aquelas que náo se mostram imediatamente - se revelem e possam ser apropriadas pela consciência. Por outro lado, nessa prova prática o homem abstrai o modus operandi adequado à finalidade posta. Os conhecimentos assim adquiridos permitem que o homem julgue a utilidade dos objetos, podendo guardálos e aperfeiçoá-los para usos posteriores ou descartá-los, se desprovidos de valor. Nascem, assim, os instrumentos de trabalho como materialidade dos conhecimentos que foram abstraídos no curso da atividade. Por isto, Leontiev (1978, p. 82) entende que o instrumento é portador da "[...] primeira verdadeira abstração consciente e racional, da primeira generalização consciente e racional", razão porque "[...] dispor de um instrumento não 
significa simplesmente possuí-lo, mas dominar o meio de ação de que ele é o objeto material de realização".

O mesmo ocorre no âmbito da práxis social, cujo objetivo é incidir sobre a consciência dos indivíduos dirigindo suas decisóes alternativas. Com efeito, estas atividades pressupóem um conhecimento do homem como ente singular - seu comportamento, suas inclinaçóes, suas pulsóes - e um conhecimento do homem como ente enredado na construção social. A este respeito, Lukács (2007, p. 235) afirma:

[...] assim como, no próprio trabalho, o saber real sobre os processos naturais envolvidos em cada caso concreto é imprescindível para poder desenvolver com êxito o intercâmbio orgânico da sociedade com a natureza, do mesmo modo um certo saber sobre a natureza dos homens, sobre suas recíprocas relaçôes sociais e pessoais, é aqui indispensável para induzi-los a efetuar as posiçóes teleológicas desejadas.

Estes conhecimentos e saberes evoluem pari passu ao desenvolvimento da sociabilidade, sedimentando-se na esfera do hábito, nos costumes, na tradição. Uma vez que estes são os principais vetores de fixação da experiência humana nas sociedades primitivas, a longevidade de uma pessoa impóe-se como premissa incontornável do domínio do saber, dos conhecimentos e valores imprescindíveis ao convívio social e à transformação da natureza. Esta é a base material do prestígio desfrutado pelos anciãos em sociedades tradicionais. Posteriormente, com a evolução da linguagem articulada e a invenção da escrita, o conhecimento do homem e da sociedade passa a ser tratado sistematicamente, segundo metodologias específicas, originando-se, desta forma, as Ciências Humanas.

O conjunto dos métodos e técnicas de aquisição deste conhecimento e intervenção sobre a conduta dos homens, e sobre as leis sociais corresponde, no plano da práxis social, aos instrumentos utilizados no trabalho. Basta pensar nos instrumentos metodológicos da Sociologia e da Psicologia para se ter uma ideia da similaridade que estabelecemos com o trabalho. Em ambos os casos, trata-se de conhecer o mais profundamente possível o objeto (uma fração da natureza, a regularidade social, o comportamento individual) para estabelecer, sobre ele, formas de intervenção eficazes, consoante as finalidades 
que presidem a atividade em questão. Os conhecimentos, saberes, modus operandi assim objetivados fazem parte da experiência sócio-histórica já referida.

Estas objetivações da práxis social não podem vir a ser senão mediadas por outra criação pertencente exclusivamente ao mundo humano, a linguagem. As próprias relaçóes travadas pelos homens na produção material da vida não poderiam se erguer sem o seu concurso. A linguagem constitui, portanto, uma forma de objetivação tão universal quanto o próprio trabalho e as relações sociais. Ela não é somente fruto das relações sociais, senão uma mediação fundamental destas mesmas relaçôes. Ela nasce por necessidade do intercâmbio dos homens e como expressão material das abstraçóes operadas no curso da atividade humana, porquanto, além de mediar a reciprocidade social, fixa e veicula os conhecimentos, saberes, valores engendrados na esfera do trabalho e da práxis social. Trata-se, portanto, de um dos vetores materiais decisivos da continuidade social, funcionando, ao mesmo tempo, como esteio da experiência passada e força propulsora da sociabilidade.

Para cumprir as funções sociais referidas, a linguagem tem de erguerse como um complexo particular, com estrutura e legalidade próprias. Basta pensar na estrutura de signos e no conjunto de regras gramaticais que constituem uma língua para se ter a exata noção da autonomia relativa que a linguagem adquire na sua evolução. Com a criação da escrita, a linguagem adquiriu não apenas mais uma potente forma de sedimentação e generalização da experiência humana, senão, também, um veículo material de autofixação no fluxo da história. É este seu caráter objetivo e autolegal que lhe confere o estatuto de objeto de uma ciência particular: a Linguística. Em uma das passagens em que trata deste complexo social, Lukács (1981b, p. 200-201) afirma:

A linguagem [...] depende fortemente de todas as transformaçóes da vida social, mas, ao mesmo tempo, o seu desenvolvimento é determinado, de modo decisivo, pela sua própria autolegalidade. [...] $\mathrm{O}$ desenvolvimento da linguagem procede por leis próprias, mas em contínua articulação, quanto aos seus conteúdos e às suas formas, com a sociedade de cuja consciência ela é órgão. Com o passar do tempo náo se pode verificar, na linguagem, nenhuma 
mudança que não corresponda às suas leis internas. Mas o impulso, conteúdo e forma destas mudanças procedem do complexo social que produz as alegrias e as dores, as açôes e as catástrofes dos homens [...] [complexo que] cria o espaço real no qual a legalidade interna da linguagem pode operar tanto em sentido positivo quanto em sentido negativo.

A linguagem constitui, pois, uma forma de ser elaborada socialmente que, portanto, se defronta com o indivíduo singular como objetividade. Ora, na medida em que se trata de um veículo da experiência humana e um meio de interação dos homens, a linguagem é mediação fundamental da integração do indivíduo com a comunidade ou com o gênero humano. Por este motivo, apropriar-se de sua estrutura, de sua legalidade e de sua funcionalidade é uma das premissas fundamentais da formação do homem singular. E isto significa que cada indivíduo desenvolva em si, mediado pela ação dos outros, as estruturas psicogenéticas e sociais encarnadas na linguagem. A fala e os sinais que servem de comunicação na vida prática são, em geral, apropriados no próprio convívio social da criança pequena com os adultos. A escrita e a leitura, entretanto, por serem formas de objetivação mais elaboradas, só podem ser apropriadas, regra geral, por meio de atividades metódicas de ensino, desenvolvidas pelos adultos com as crianças ou pelos professores com os alunos.

Os desdobramentos feitos acima tinham a intenção de esclarecer que as atividades exercidas sobre os próprios homens mantêm a mesma estrutura do trabalho. Elas são atividades objetivadoras constituídas de finalidades, busca dos meios (quando ocorre o conhecimento do homem e da sociedade), escolha entre alternativas e realização prática. Mas no seu ser-precisamente-assim exibem uma forma de ser que se diferencia do trabalho. É decisivo considerar, primeiramente, a natureza ontologicamente diferente do objeto da práxis social e aquele do trabalho no sentido estrito. Com efeito, as atividades que compóem a práxis social são presididas por posiçôes teleológicas secundárias, cujo "[...] conteúdo essencial [...] é a tentativa de induzir uma outra pessoa (ou grupo de pessoas) a realizar algumas posiçóes teleológicas concretas” (LUKÁCS, 1981a, p. 56). O objeto aqui é o próprio homem vivendo em sociedade. Então, já não se trata de moldar um objeto mudo e indiferente ao que se pretende, mas 
de induzir o homem a assumir, por si mesmo, determinadas escolhas que concernem à necessidade do grupo, da comunidade, da sociedade. O que se pretende com estas atividades é atuar sobre a consciência dos homens para que desenvolvam suas atividades no trabalho e no convívio social de uma forma determinada. A ação aqui é desencadeada sobre sujeitos portadores de consciência, que reagem ativamente à pressão social e decidem entre possibilidades reais.

A segunda e decisiva diferença deriva da primeira. Dado o caráter ativo dos sujeitos que sofrem a ação no interior da práxis social, estas atividades estão sujeitas a maior variabilidade entre as finalidades postas idealmente e os resultados da objetivação. Por causa da natureza essencialmente mutante e mutável do objeto da práxis social, o conhecimento (do homem e da sociedade) se apresenta como mais complexo e mais difícil de ser determinado com precisão. A própria forma de organização e a dinâmica do objeto levam mais tempo para serem abstraídas, muitas vezes só podendo ser analisadas post festum. O conhecimento auferido em cada momento é sempre parcial, temporário e variável.

Tendo isto em consideração, compreende-se por que, muitas vezes, o resultado da ação desenvolvida sobre os homens está em clara contradição com o que se desejava no início. Isto se deve ao fato de que as finalidades expressam a necessidade posta pela forma de cooperaçáo instaurada no trabalho e pela reciprocidade social, ou seja, pela reprodução da sociedade como um todo. É daí que partem as atividades, que tendem a se institucionalizar (a educação, por exemplo), visando a direcionar a conduta dos indivíduos. Mas são estes que objetivarão as açóes esperadas e o fazem escolhendo entre alternativas existentes. Nesta escolha, tanto pode acontecer um reforço do status quo dominante quanto sua negação - ainda que parcial. Por isto mesmo, na práxis social é impossível alcançar o grau de univocidade auferido na atuação do homem sobre a natureza. O resultado final é sempre algo de heterogêneo, diferente e até contraditório em comparação com as finalidades postas inicialmente, precisamente e na medida em que os indivíduos não são passivos diante da ação sofrida. Eles reagem ativamente e com sua ação transformam o que já foi institucionalizado, mudam a própria sociedade, interferem nos rumos da história. 


\section{Natureza e especificidade da educaçáo}

Os desdobramentos feitos acima conduzem à conclusão de que a experiência sócio-histórica ou a generalidade humana é posta sobre a base natural pelo trabalho e pelo conjunto da prática social dos homens. Ela deixa de ser algo incorporado aos atributos biológicos da espécie para se fixar exteriormente por meio do processo de objetivaçáo. Eis por que os indivíduos precisam se apropriar desta experiência objetivada como condiçáo de sua inserção no mundo genuinamente humano. A apropriação se processa por meio da atividade que o indivíduo desenvolve no trabalho e no conjunto das práticas sociais. Estas atividades não se realizam na solidão, mas sempre mediadas por relaçôes travadas entre os indivíduos. Por isto, a apropriação que se dá no plano individual/subjetivo é sempre, e necessariamente, mediada pela açấo de outros homens. Nas palavras de Leontiev (1978, p. 272):

As aquisiçóes do desenvolvimento histórico das aptidôes humanas não são simplesmente dadas aos homens nos fenômenos objetivos da cultura material e espiritual que os encarnam, mas são aí apenas postas. Para se apropriar destes resultados, para fazer deles as suas aptidôes, "os órgãos da sua individualidade", a criança, o ser humano, deve entrar em relação com os fenômenos do mundo circundante através doutros homens, isto é, num processo de comunicação com eles. Assim, a criança aprende a atividade adequada. Pela sua função, este processo é, portanto, um processo de educaçáo.

Esta citação elucida o lugar onde nasce e opera o complexo da educação, e abre importantes sendas para a captura e exposição da sua natureza e especificidade no seio da práxis social. A educação se situa no âmbito das relaçôes travadas entre os homens e se presta a mediar a apropriação ou reprodução na esfera individual/subjetiva do patrimônio genérico (ou experiência sócio-histórica) objetivado socialmente. A necessidade que está na sua origem, é preciso realçar, já não se refere diretamente à relação do homem com a natureza, mas às relaçôes travadas entre homens. Mesmo nas comunidades originárias, onde o gradiente de relaçôes sociais é ainda incipiente e, talvez, se ligue de forma mais imediata à produção material 
da vida, resta o fato iniludível de que são as relaçóes sociais que póem a necessidade da atividade educativa. Há, pois, já na situação originária uma nítida diferenciação entre o trabalho e a atividade educativa. Com efeito, o trabalho é uma atividade que realiza o metabolismo do homem (sociedade) com a natureza; a educação surge como demanda do conjunto de relaçóes que os homens contraem na produção da vida material. Com justeza, podemos, pois, afirmar que a educação é uma categoria do âmbito da reprodução social.

Neste particular, a tese aqui defendida incorpora a orientação teóricometodológica do professor Dermeval Saviani (2003), mas a supera na medida em que procura identificar a necessidade originária da educação, o impulso que está na sua gênese, e sobre esta base expor sua especificidade no confronto com o trabalho. ${ }^{1}$ No ensaio intitulado "Sobre a natureza e especificidade da educação", Saviani (2003) opera uma homogeneização dos conceitos de trabalho e educação, deixando de lado a diferenciação ontológica posta já na necessidade que está na gênese de uma e de outra categoria. Ao reconhecer no trabalho o fundamento primeiro da vida humana, o filósofo-educador deriva que todos os outros fenômenos humanos surgem como necessidade posta pelo trabalho, bem como constituem, também, um tipo de trabalho. É isto que se lê na seguinte passagem: "Dizer, pois, que a educação é um fenômeno próprio dos seres humanos significa afirmar que ela é, ao mesmo tempo, uma exigência do e para o processo de trabalho, bem como é, ela própria, um processo de trabalho" (SAVIANI, 2003, p. 12). A porta de entrada para a exposição do ser-precisamente-assim de uma categoria social é perdida aqui, precisamente a compreensão da necessidade que está na origem da categoria em estudo e, a partir daí, sua função social específica. É disto que o presente artigo se ocupa daqui em diante.

A continuidade da experiência sócio-histórica se processa por meio dos atos singulares dos indivíduos que, uma vez objetivados, reentram no gradiente das relaçóes existentes, formando sínteses complexas que vivificam e esteiam a dinâmica da sociedade como um todo. A reprodução social consiste neste ininterrupto processo de transformação dos elementos fixados na experiência sócio-histórica em elementos subjetivos, e na objetivação das forças e potências subjetivas que passam a constituir a continuidade histórica. A educação é um dos complexos de atividade social que realizam as transformaçóes de uma esfera na outra. Com efeito, a polaridade operante no seio da reprodução social implica que os indivíduos tenham que reproduzir 
em seus atos - de forma desigual e contraditória, mas sempre necessária - as faculdades, os conhecimentos, as habilidades, os valores que foram sedimentados na experiência social e fazem parte do patrimônio genérico alcançado. A educação, a exemplo de outras atividades sociais (a arte, por exemplo), insere-se no interior dessa mediação entre experiência social objetivada e sua reprodução no plano da subjetividade.

A especificidade da educação reside na sua função precípua, qual seja, a de mediar a apropriação, no plano individual, do patrimônio genérico acumulado na experiência sócio-histórica. Desta forma, o complexo social da educação constitui-se do conjunto das açôes exercidas por uns homens sobre os outros com o fim de que estes se apropriem das forças materiais e espirituais produzidas e sedimentadas no curso da experiência sóciohistórica. Como já observamos, o indivíduo apropria-se desta experiência ativamente, por meio das diversas atividades externas e internas, no trabalho e na práxis social. Porém, a própria atividade é, ela mesma, um produto histórico, e não uma dimensão inscrita no patrimônio genético da espécie, porquanto cada homem tem de conquistá-la, isto é, tem de reproduzi-la subjetivamente, tem de apropriar-se dela. A educação é esta ação que proporciona a aprendizagem das atividades diretamente ligadas à produção material da vida, bem como do conjunto de atividades que compóem a práxis social. $\mathrm{O}$ indivíduo aprende a ser homem à medida que aprende a se objetivar de acordo com o padrão social existente, e este aprendizado é realizado por meio dos atos educativos. Como a linguagem, que exerce função essencial no curso de toda e qualquer forma de atividade humana, a educação se presta a mediar a assimilação, pelos indivíduos, da própria atividade em todos os campos da vida humana.

$\mathrm{O}$ ato de dirigir-se a outro homem com uma palavra ou um gesto para lhe ensinar uma operação de trabalho é ontologicamente diferente do ato mesmo de trabalho, ainda que ambos se processem simultaneamente. A atividade que procura urdir a comunidade de interesses e a unidade de ação de um grupo, categoria ou classe para disputar o poder com outro grupo, categoria ou classe é ontologicamente diferente das atividades que tencionam transmitir conhecimentos, métodos, estratégias de ação que capacitarão os indivíduos a se posicionarem no âmbito do conflito social e a executarem as "ferramentas" da luta política. Os juristas, legisladores e operadores do Direito certamente necessitam da mediação da educação 
para dominarem suas atividades específicas, mas o exercício do direito no sentido estrito não se confunde com a educação. $\mathrm{O}$ trabalho, a política, $\mathrm{o}$ Direito e todas as atividades sociais não podem existir no fluxo da história senão pelo auxílio da educação. Todavia, tomados em si mesmos, se levadas em conta a necessidade social que está na sua gênese e a função específica que cumprem na dinâmica social, estes complexos de atividade social se revelam ontologicamente diferentes da atividade educativa.

A identificação da necessidade e da função específica da educação no gradiente das atividades sociais permite emitir nova crítica ao construto do eminente professor Dermeval Saviani. No texto já citado (SAVIANI, 2003), o autor opera, primeiramente, a identidade entre o trabalho e todas as demais atividades humanas. $\mathrm{O}$ segundo passo consiste em buscar a especificidade das atividades que se voltam sobre os próprios homens em contraste com o trabalho que transforma a natureza. Para tanto, recorre a meios estritamente formais, qualificando as atividades que produzem bens tangíveis como "trabalho material" e as demais como "trabalho não material”. A educação, segundo pensa, participaria desta segunda rubrica, localizando-se, entretanto, num recôndito mais estrito que comportaria os trabalhos não materiais cuja produção se dá simultaneamente ao consumo do que é produzido. E exemplifica com a realização de uma aula, ato cujo produto é consumido concomitante à produção.

A transposição do vocabulário que expressa a ação do homem sobre a natureza (produção, consumo) para o campo educacional é um equívoco que deriva da premissa colocada no início: a homogeneização formal entre trabalho e o conjunto das práticas sociais. Mais importante que isto, entretanto, é a concepção de matéria subjacente à abordagem de Saviani. Consoante seu escrito, a materialidade estaria circunscrita aos objetos tangíveis, palpáveis, visíveis, com o que as objetivaçóes postas em vida pela práxis social habitariam o mundo da não-materialidade. As ideias, os conceitos, os símbolos, os valores, os elementos da cultura reconhecidos pelo autor como objeto do trabalho educativo seriam não materiais. Na perspectiva ontológica, os "elementos culturais" referidos pelo autor têm existência material tanto quanto a pedra ou o automóvel. São "elementos" exteriores à consciência dos indivíduos, elaborados e postos como objetividade pelo conjunto das atividades sociais; fazem parte das objetivaçóes da práxis social e, como tais, são partes constitutivas da 
materialidade da vida social. Como materialidade posta pela ação recíproca dos homens e acumulada no curso da história, os elementos da cultura humana precisam ser apropriados pelos indivíduos singulares e reproduzidos em suas ações. Somente assim são possíveis a continuidade da experiência sócio-histórica e a formação da individualidade.

É o próprio Saviani quem, mais tarde, sentirá o peso do equívoco cometido ao escrever outro ensaio dedicado a expor a materialidade da ação pedagógica. Dado que o título deste escrito contrasta frontalmente com a formulação anterior, o autor vê-se obrigado a esclarecer que a nãomaterialidade antes defendida

[...] significa que a atividade que a constitui se dirige a resultados que não são materiais [...]. No entanto [continua ele no parágrafo seguinte], nós sabemos que a ação que é desenvolvida pela educação é uma ação que tem visibilidade, é uma ação que só se exerce com base em um suporte material. Logo, ela realiza-se num contexto de materialidade. (SAVIANI, 2003, p. 106).

O "contexto de materialidade" a que se refere trata das condições sóciohistóricas em que se efetiva o fenômeno educativo. Nas palavras do autor, "Estas condições materiais configuram o âmbito da prática" (SAVIANI, 2003, p. 106-107). Do ponto de vista dos resultados, a educação é um trabalho não material; do ponto de vista do processo, ela é uma atividade que se "realiza num contexto de materialidade", isto é, ela se efetiva praticamente sobre a base de condiçóes materiais postas pela sociedade. Como o resultado respeita a conhecimentos, símbolos, saberes, habilidades, objetivações sedimentadas na experiência sócio-histórica, entende o autor que se trata de elementos não materiais. A homogeneização formal do início cobra aqui, mais uma vez, seu preço.

O entendimento do caráter ativo da apropriação, tal como demonstrado atrás, coloca um degrau a mais na elucidação da atividade educativa e dá base para a incorporação crítica de um postulado muito difundido na corrente pedagógica histórico-crítica que busca expressar a natureza da atividade educativa. Depois de realizar os desdobramentos acima referidos, Saviani (2003, p. 13) conclui: 
Podemos, pois, dizer que a natureza humana não é dada ao homem, mas é por ele produzida sobre a base da natureza biofísica. Conseqüentemente, o trabalho educativo é o ato de produzir, direta e intencionalmente, em cada indivíduo singular, a humanidade que é produzida histórica e coletivamente pelo conjunto dos homens.

Esta passagem incorpora, com devida propriedade, a tese defendida no presente ensaio de que a experiência sócio-histórica ou a generalidade humana é objetivada pela ação dos homens em sociedade. Com justeza, afirma o autor que ela é posta sobre a base da natureza biofísica. Porém, dada a homogeneização formal operada no início, mesmo uma ideia tão profícua como esta não encontra a forma adequada de se expressar. Consoante o que se expôs sobre o caráter ativo da apropriação, não se pode conceituar a atividade educativa como um trabalho que produz nos indivíduos singulares a humanidade que é produzida socialmente. Esta objeção se funda na diferença ontológica, já demonstrada, existente entre o objeto do trabalho - como atividade que relaciona o homem e a natureza - e o objeto da práxis social - como o conjunto de atividades que relacionam os homens entre si.

O trabalho constitui uma mediação tanto quanto as outras atividades sociais, mas seu objeto é mudo. Na práxis social, o objeto é o próprio homem como ente envolvido na sociedade. A ação exercida já não produz diretamente, mas desencadeia um processo incisivo sobre a consciência dos indivíduos, buscando direcionar suas decisóes, seus atos, sua conduta. Para tanto, a atividade social atua mediada pelas objetivações que fazem parte da experiência sócio-histórica: conhecimentos, saberes, valores. À proporção que estes conteúdos elaborados socialmente são apropriados pela consciência e incorporados à conduta prática dos indivíduos é que as finalidades que estavam no início se objetivam. A objetivação, neste caso, é mediada pelas decisões dos homens que sofrem a ação, razão por que seus resultados não podem alcançar o grau de univocidade comparecente na açáo do homem sobre a natureza. Por isto, afirmar que o trabalho educativo produz algo nos indivíduos não é adequado, inclusive porque esta formulação abre o flanco para as críticas interessadas do irracionalismo - muito presente na teoria educacional contemporânea - no tocante ao tema da relação entre sujeito e objeto da atividade educativa. 
A educação é uma atividade mediadora que atua diretamente nos processos de apropriação do patrimônio genérico no plano da individualidade. Trata-se de um duto dinâmico por meio do qual a generalidade se realiza no plano subjetivo e as potências subjetivas se tornam objetivas. Esta forma de colocar a questão não retira o caráter ativo da educação, mas reconduz as coisas ao seu devido lugar. Com efeito, mediar não significa atar dois opostos, tampouco estabelecer uma ponte inerte entre um e outro. A mediação só pode existir como processo e resultado da ação objetivadora, consciente, dos homens. Como processo, ela é o movimento provocado pela ação consciente do homem que opera sobre a base de premissas materiais existentes, inserindo suas forças e propriedades em novas conexóes, mudando sua forma. No curso desse movimento, o sujeito exercita suas forças, põe em vida as potências que estavam adormecidas, transforma-se ao mesmo tempo em que imprime transformaçóes no objeto. Como resultado, a mediação se expressa sob a forma das novas objetividades que sintetizam elementos originalmente contrapostos e heterogêneos, operando transformaçóes na objetividade e na subjetividade. No curso do trabalho, a teleologia e a causalidade se sintetizam superando a heterogeneidade inicial, dando origem a um objeto que, sendo uma causalidade posta, não é idêntica à forma causal inicial, tampouco à finalidade posta idealmente. Por seu turno, a subjetividade que pôs e operou a ação laborativa sofreu transformaçóes substantivas. Ao final, a matéria está trabalhada, e a subjetividade, transformada.

O estudo dos escritos de juventude de Marx realizado pelo professor Frederico (1995) é instrutivo quanto à tese da mediação como atividade prático-material. Segundo afirma, Marx teria superado Hegel nesta questão ao arrancar a categoria mediação da sua natureza formal, abstrata, e demonstrá-la como momento resolutivo do real. Como atividade material, ela deixa de ser o meio pelo qual os opostos se anulam e se equilibram (construto hegeliano) para constituir a forma de movimento por meio da qual o homem, como parte da natureza, se torna um ser automediador na medida em que pode transcender as determinaçóes naturais (mudando sua forma) e criar um mundo social (a experiência sócio-histórica ou a generalidade humana). Para Frederico (1995, p. 175), na perspectiva monista do jovem Marx, "[...] as relaçóes dos homens com a natureza são vistas por intermédio da mediação da atividade material”. ${ }^{2}$ 
O caráter ativo da mediação, tal como demonstrado no trabalho, comparece em toda a práxis social. Assim, a educação é uma mediação na medida em que é constituída do conjunto de atividades finalistas que póem em vida um movimento por meio do qual as forças genéricas se realizam na subjetividade, engendrando nela as faculdades desenvolvidas historicamente. Com isto, a mediação educativa potencializa as forças do indivíduo que, uma vez objetivadas e engastadas no continuum social, implicam transformaçóes no plano objetivo e no desenvolvimento da capacidade vital da sociedade como um todo. A mediação operada pela educação resulta em transformações no plano subjetivo e objetivo, na esfera da individualidade e na da generalidade, no sujeito particular e na própria sociedade onde ele vive e se reproduz.

À diferença da mediação operada pelo trabalho, a atividade educativa procura incidir sobre a consciência, sobre a conduta, sobre a prática social dos indivíduos, não diretamente como faz o marceneiro com a madeira. $\mathrm{A}$ educação atua sobre a consciência sempre por meio do ensino de conteúdos elaborados socialmente. Tais conteúdos correspondem a necessidades postas pelo grau de desenvolvimento das atividades econômicas e pelo grau de complexificação das relaçóes sociais. Assim, o resultado final dos objetivos impressos na atividade educativa depende da quantidade e da qualidade da apropriação realizada na consciência dos educandos e, ainda mais, das escolhas que estes operarão diante dos imperativos do presente. Os usos do aprendizado variarão, não apenas porque os problemas postos pela realidade são sempre mutáveis e mutantes, mas fundamentalmente porque a dinâmica social sempre póe possibilidades concretas de escolhas negativas em face dos valores prevalecentes. Por isto, as escolhas individuais podem tomar sentido contrário aos objetivos que estavam na origem do ato educativo. Quer-se dizer que os elementos culturais apropriados pela subjetividade podem se tornar instrumentos a serviço do reforço do status quo ou da insurreição diante do padrão social vigente.

A educação é, pois, uma atividade objetivadora, a exemplo do trabalho e das outras atividades que constituem a práxis social. Como tal, e resguardado o fato de que a objetivação é mediada pela apropriação e pelas escolhas dos indivíduos que sofrem a ação, a atividade educativa exibe uma estrutura similar à do trabalho, a saber: o momento primário é o da necessidade que é transformada em finalidade pela consciência; a posição 
de finalidades implica que se busquem os meios de sua execução, momento em que o sujeito é impulsionado ao conhecimento mais adequado das leis que regem a sociedade e o próprio comportamento do homem; de posse dos meios de realização do fim posto, resta que os sujeitos decidam, a partir de possibilidades objetivamente existentes, sobre a realização do ato educativo (se realizam ou não, quais instrumentos utilizar, que valores devem direcionar o ato, etc.). Como se elaboram as finalidades educativas e qual seu sujeito e objeto são questóes que se devem delinear para concluir este ensaio.

\section{Finalidades, sujeito e objeto da atividade educativa}

Lukács (1981b, p. 153) afirma: “Toda sociedade reclama dos próprios membros uma dada massa de conhecimentos, habilidades, comportamentos etc.", necessidades às quais a educação procura responder. Mais adiante, assegura que a essência da educação "[...] consiste em influenciar os homens a fim de que, frente às novas alternativas da vida, reajam do modo socialmente desejado" (LUKÁCS, 1981b, p. 153-154). As afirmaçôes se referem ao fato de que as necessidades do complexo educativo são postas pela dinâmica social e estão concernidas em duas ordens: o padrão em que se encontram as forças produtivas, e os valores e ideologias predominantes na sociedade. Uma vez que a continuidade social tem de se processar por meio dos atos singulares, a própria sociedade exige dos indivíduos que dominem determinados conhecimentos e habilidades, e incorporem em sua conduta os valores prevalecentes. ${ }^{3}$ A necessidade social é o momento ontologicamente primário no desdobramento das finalidades inscritas na ação educativa.

A necessidade social se expressa, primeiramente, sob a forma de conteúdos necessários à inserção dos indivíduos na produção econômica e na prática social. Tais conteúdos perpassam toda a prática social, imiscuindo-se no conjunto de relaçôes que o indivíduo trava com os outros do nascimento até a morte. É assim que a necessidade social se transforma em finalidades que presidem a ação educativa na família, na comunidade, até assumir uma forma mais sistematizada e metódica nas instituiçóes escolares. Os conteúdos que formam as disciplinas e as normas dos rituais escolares consistem na transposição da necessidade social para a particularidade dos sistemas educacionais e das escolas. A atividade educativa é, pois, presidida por finalidades que respondem a necessidades postas pela dinâmica 
reprodutiva da sociedade. Ademais, o campo de possibilidades de realização das finalidades educacionais é, também e fundamentalmente, determinado pela dinâmica social como um todo.

Aqui só é possível aludir a que os conteúdos socialmente elaborados incorporam os valores, normas de conduta social, concepçóes de mundo que expressam, espiritualmente, a trama das relaçóes sociais. Estes elementos incidem sobre a prática social dos indivíduos, capacitando-os a atuarem segundo as exigências sociais e direcionando suas escolhas alternativas. Neste exato sentido, a educação constitui uma atividade inerentemente ideológica. Ela expressa e veicula os valores e ideias que selam a reciprocidade social em cada época histórica, como também os valores e ideias que se vinculam aos interesses das classes particulares. Todo ato educativo é, pois, transpassado por ideologias, seja no sentido de uma concepção abrangente da natureza/ homem/sociedade, seja no sentido dos construtos ideais e valorativos que, sendo expressão de forças incrustadas no antagonismo estrutural, disputam a hegemonia no interior do conflito social. ${ }^{4} \mathrm{~A}$ afirmaçáo segundo a qual cada formação social particular engendra a educação de que necessita e, por esta via, forma o sujeito correspondente expressa uma profunda verdade histórica.

A necessidade social não pode se afirmar sobre a subjetividade, senão pela mediação de homens e mulheres que a assumam sob a forma de finalidades. Já se afirmou que a experiência sócio-histórica só pode ser apropriada no plano subjetivo pela mediação da ação dos outros homens. Ressalvado o fato de que o homem se educa em todas as circunstâncias de sua vida, deriva-se que a atividade educativa só pode ter como sujeitos agentes aqueles indivíduos que são portadores da experiência acumulada socialmente, isto é, as gerações adultas. Como portadoras da experiência sócio-histórica, as gerações adultas assumem as necessidades sociais como suas finalidades e as objetivam atuando com as crianças. Com o surgimento da educação escolar - cuja necessidade é posta pela complexificação da divisão do trabalho e das objetivaçóes humanas -, o fato da idade é relativizado, porque um jovem pode, já muito cedo, se tornar portador da cultura humana e ser um eminente professor numa área determinada. Mesmo assim, mantém-se o fato de que o educador tem de ser portador dos conhecimentos, saberes, habilidades, valores objetivados historicamente na sua área específica.

Isto torna as novas geraçóes e os educandos objetos da ação educativa? Sem dúvida, todo indivíduo se reproduz inserido num contexto social que 
lhe imprime determinadas exigências, mesmo que anonimamente. Todo indivíduo sofre a ação educativa das geraçóes adultas e dos professores. Porém, cada um reage ativamente ao imperativo posto pela sociedade e pela educação, desenvolvendo uma atividade específica no curso da qual, inclusive, opera decisões que podem tanto aquiescer à norma prevalecente como negála. Assim, as novas geraçóes e os educandos sofrem a ação educativa ao mesmo tempo em que são, também e irremediavelmente, sujeitos do seu processo educativo. $\mathrm{O}$ caráter ativo da apropriação não é negado na prática educativa, mas se patenteia como pressuposto fundamental.

Há, nesse sentido, um momento de identidade entre educador e educando: ambos são sujeitos do processo educativo. Como tais, desenvolvem uma atividade específica sobre os conhecimentos, saberes, habilidades, valores acumulados socialmente e requeridos de cada indivíduo. Mas este momento de identidade não exclui as diferenças ontologicamente postas pela posição e função de cada um destes agentes na estrutura da atividade educativa. A posição e a função social do educador supóem que ele tenha já se apropriado dos elementos culturais concernidos na sua área de atuação. A posição e a função do educado supóem que ele é carente dos elementos da cultura material e espiritual naquela área específica. Não por outro motivo, cabe ao educador a função de recolher, selecionar, organizar os elementos da experiência sócio-histórica reclamados dos indivíduos, além de estabelecer os métodos, técnicas e formas de controle do processo de ensino.

A dissolução destas diferenças faz parte de um ideário que desfecha incisivas acusaçóes sobre as escolas e que é expressão teórica do irracionalismo que caracteriza o projeto burguês na contemporaneidade, nada tendo de progressista. Que o irracionalismo burguês atual desfira ataques vigorosos ao sistema escolar das massas trabalhadoras, aos conteúdos clássicos e à própria figura do professor, compreende-se. Com efeito, a classe burguesa é a personificação da irracionalidade que preside a produção/distribuição econômica e as relaçôes sociais no mundo atual, não podendo atuar no campo do saber sistematizado, senão mediada pelo irracionalismo. Porém, os sujeitos estruturalmente interessados na transformação social não podem prescindir do controle da cultura material e espiritual acumulada historicamente. Na medida em que os elementos centrais (os clássicos, para Dermerval Saviani) da cultura constituem objetivaçóes cuja forma e cujo conteúdo envolvem alto grau de complexidade, a sua reprodução no plano 
subjetivo só pode se processar por meio de esforços metódicos, com o uso de instrumental adequado e segundo um tempo cada vez mais elástico dedicado ao ensino. Consequentemente, o aparato escolar assume importância crucial na reprodução e no progresso do patrimônio cultural construído socialmente. Para aqueles que ocupam posição subordinada na estrutura hierárquica da divisão do trabalho e da riqueza produzida socialmente, a escola constitui uma conquista da qual não podem abrir mão. Ela é parte de um patrimônio gravado nas constituiçóes da democracia burguesa à custa da luta histórica dos trabalhadores.

Defender a escola, o ensino sistematizado de alta qualidade para as novas geraçóes no mundo em que vivemos, é apostar numa das condiçóes necessárias - embora não suficiente - da superação da alienação e da barbárie que assolam a vida das maiorias. Neste aspecto, nos coadunamos inteiramente com o professor Dermeval Saviani.

\section{Notas}

1 Para uma compreensão dos pontos de discordância com Saviani, conferir Macário (2005).

2 Sobre o posicionamento de Marx em função de Hegel e Feuerbach, inclusive sobre a categoria da mediação, conferir Frederico e Sampaio (2006).

3 A este respeito, conferir a significativa contribuição de Fernández Enguita $(1989$; 1993).

4 Sobre a concepção lukácsiana de ideologia, conferir o valioso artigo de Vaisman (1989).

\section{Referências}

DUARTE, Newton. A individualidade para-si: contribuição a uma teoria histórico-crítica da formação do indivíduo. 2. ed. Campinas, SP: Autores Associados, 1999.

FERNÁNDEZ ENGUITA, Mariano. A face oculta da escola: educação e trabalho no capitalismo. Porto Alegre: Artes Médicas, 1989. 
FERNÁNDEZ ENGUITA, Mariano. Trabalho, escola e ideologia: Marx e a crítica da educação. Porto Alegre: Artes Médicas, 1993.

FORTES, Ronaldo Vielme. Trabalho e gênese do ser social na "ontologia" de George Lukács. 2001. Dissertação (Mestrado em Filosofia) - Programa de Pós-Graduação em Filosofia, Faculdade de Filosofia e Ciências Humanas, Universidade Federal de Minas Gerais, Belo Horizonte.

FREDERICO, Celso; SAMPAIO, Benedicto Artur. Feuerbach e as mediaçóes. Revista Novos Rumos, São Paulo, ano 3, n. 8/9, São Paulo: Novos Rumos; Instituto Astrogildo Pereira, p. 77-115, 1988.

FREDERICO, Celso. O jovem Marx 1843-44: as origens da ontologia do ser social. São Paulo: Cortez, 1995.

; SAMPAIO, Bendito Arthur. Dialética e materialismo: Marx entre Hegel e Feuerbach. Rio de Janeiro: Editora da UFRJ, 2006. LENIN, Vladimir Ilith. Materialismo y empiriocriticismo. Moscú: Progreso, 1979.

LEONTIEV, Alexis. O desenvolvimento do psiquismo. Portugal: Livros Horizonte, 1978.

LESSA, Sérgio. Mundo dos homens: trabalho e ser social. São Paulo: Boitempo, 2002.

. Trabalho imaterial: Negri, Lazzarato e Hardt. Revista Estudos de Sociologia, ano 6, n. 11, p. 119-143, São Paulo, jul./dez. 2001.

LUKÁCS, Györg. Il lavoro. In: . Per l'ontologia dell'essere sociale.

Tradução de Ivo Tonet. Roma: Riuniti, 1981a. v. 2, p.11-131.

. La riproduzzioni. In: . Per l'ontologia dell'essere sociale. Tradução de Sérgio Lessa. Roma: Riuniti, 1981b. v. 2, p. 135-331.

. Ontologia do ser social: os princípios ontológicos fundamentais de Marx. Tradução de Carlos Nelson Coutinho. São Paulo: Livraria Editora Ciências Humanas, 1979.

- O jovem Marx e outros escritos de filosofia. Tradução de Carlos Nelson Coutinho e José Paulo Netto. Rio de Janeiro: Editora da UFRJ, 2007. 
MACÁRIO, E. Trabalho, reprodução social e educação. 2005.151 f. Tese (Doutorado em Educação Brasileira) - Programa de Pós-Graduação em Educação Brasileira. Faculdade de Educação da Universidade Federal do Ceará, 2005, 151 p. Disponível em:< http://www.cetros.blogspot.com>. Acesso em: 25 dez. 2008.

MARX, K. O capital: crítica da economia política: livro primeiro: volume I. São Paulo: Abril Cultural, 1983.

MARX, K. Formaçóes econômicas pré-capitalistas: introdução de Eric Hobsbawm. Tradução de João Maia. 6. ed. São Paulo: Paz e Terra, 1991. SAVIANI, Dermeval. Pedagogia histórico-critica: primeiras aproximaçóes. 8. ed. Campinas, SP: Autores Associados, 2003.

TONET, Ivo. Educação, cidadania e emancipação humana. Ijuí: Editora da Unijuí, 2005.

VAISMAN, Ester. A ideologia e sua determinação ontológica. Revista Ensaio, n. 17-18, p. 399-444. São Paulo: Ensaio, 1989. 


\section{Work, social praxis and Education: notes for a theory of educational activity}

\section{Abstract}

This article discusses the nature and specificity of educational activity in the realm of social praxis. It first presents the categories of objectivation and appropriation as constitutive moments of work and social praxis. Upon these foundations, it shows the need, the social function, the subject and object of educational activity. The text is based on ideas of Lukács and Leontiev.

Key words: Education -Social factors. Education for work.

\section{Trabajo, praxis social y Educación: notas para una teoría de la actividad educativa}

\section{Resumen}

El presente artículo discute la naturaleza y la especificidad de la actividad educativa en el ámbito de la praxis social. Inicialmente, expone las categorías de objetivación y apropiación como momentos constitutivos del trabajo y de la praxis social. A partir de ese fundamento, muestra la necesidad, la función social, el sujeto y el objeto de la actividad educativa. El texto se fundamenta en el pensamiento de Lukács y en Leontiev. Palabras clave: Educación. Praxis social. Trabajo.

\section{Epitácio Macário}

Rua Francisco Calaça, 1527

Bairro Álvaro Weyne

Fortaleza - Ceará

CEP: 60336-550

E-mail: e_macarius@yahoo.com.br

URL: www.cetros.blogspot.com

Recebido em: 16/3/2009

Aprovado em: 10/4/2009 